\title{
Antioxidant and antimicrobial activity of
}

\section{peptides extracted from meat by-products. A}

\section{review}

Paula Borrajo ${ }^{\mathrm{a}}$, Mirian Pateiro ${ }^{\mathrm{a}}$, Francisco J. Barba ${ }^{\mathrm{b}}$, Leticia Mora ${ }^{\mathrm{c}}$, Daniel

Franco $^{a}$, Fidel Toldrác and José M. Lorenzo ${ }^{a *}$

${ }^{a}$ Centro Tecnológico de la Carne de Galicia, Rúa Galicia No 4, Parque Tecnológico de Galicia, San Cibrao das Viñas, 32900 Ourense, Spain.

b Nutrition and Food Science Area, Preventive Medicine and Public Health, Food

Sciences, Toxicology and Forensic Medicine Department, Faculty of Pharmacy, Universitat de València, Avda. Vicent Andrés Estellés, s/n, 46100 Burjassot, València, Spain

c Instituto de Agroquímica y Tecnología de Alimentos (CSIC), Avenue Agustín

Escardino 7, 46980 Paterna (Valencia), Spain

*Corresponding author:

Email address:jmlorenzo@ceteca.net

Tel: +34 988548277 


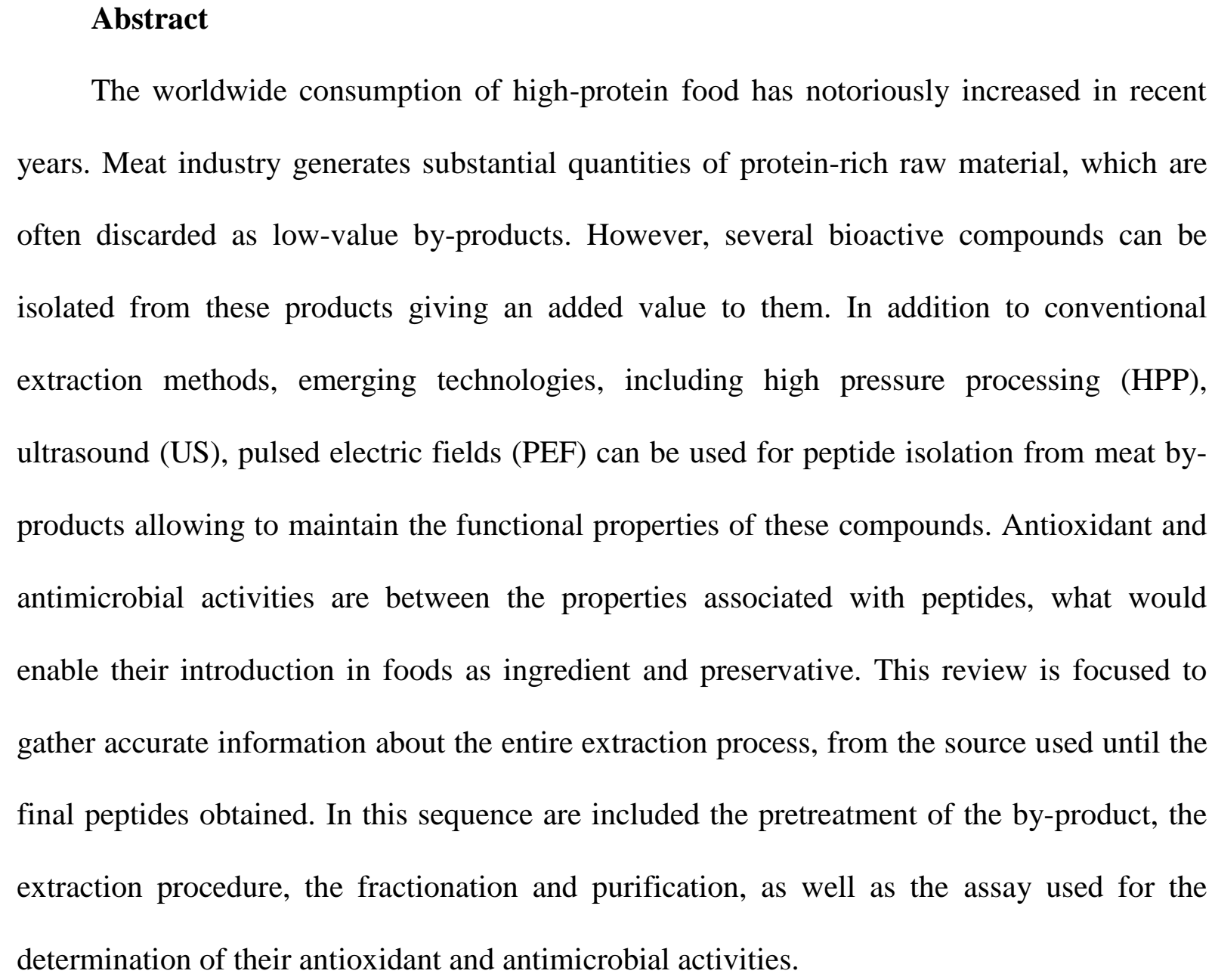

The worldwide consumption of high-protein food has notoriously increased in recent years. Meat industry generates substantial quantities of protein-rich raw material, which are often discarded as low-value by-products. However, several bioactive compounds can be isolated from these products giving an added value to them. In addition to conventional extraction methods, emerging technologies, including high pressure processing (HPP), ultrasound (US), pulsed electric fields (PEF) can be used for peptide isolation from meat byproducts allowing to maintain the functional properties of these compounds. Antioxidant and antimicrobial activities are between the properties associated with peptides, what would enable their introduction in foods as ingredient and preservative. This review is focused to gather accurate information about the entire extraction process, from the source used until the determination of their antioxidant and antimicrobial activities. extraction procedure, the fractionation and purification, as well as the assay used for the

Keywords: Bioactive; Co-products; Enzymatic hydrolysis; Meat industry; Valorization 


\section{Meat industry and by-products}

Meat industry is one of the most important industrial sectors in the world, producing around of 330 million of tons. Europe provides approximately one fifth of the world's production, being Germany, Spain, France and Italy the countries with the largest population of primary livestock (FAOSTAT 2016). This great production gives an idea of the huge amounts of disposal generated each day in processing meats and slaughterhouses (Toldrá et al. 2012), since not all the parts of animals are suitable and safe to human consumption. It is estimated that more than half of live animal weight is not appropriate for human consumption (Irshad and Sharma 2015). Europe together with Asia are the two largest consumers of meat by-products, especially those that have as source beef and lamb (Liu and Ockerman 2001). Furthermore, the discard of these animal by-products may influence unfavorably the environment because of the increase in chemical (COD) and biochemical oxygen demand (BOD) (O'Sullivan et al. 2017; Bah et al. 2015).

Several studies have aimed to study meat by-products since a great number of bioactive compounds can be obtained from them (Ryder et al. 2016). These by-products have a high nutritional content, with proteins between the nutrients that could have functional properties (Matak et al. 2015; Toldrá et al. 2016; Pateiro et al. 2019). Bioactive peptides usually contain sequences of 2 to 20 amino acids, among them are included essential amino acids with high bioavailability that humans cannot synthesize, like hydroxymethyllysine and methylhistidine, which are not usually present in plant protein (Arihara et al. 2006; Wang et al. 2008; Vongsawasdi et al. 2014; Siti et al. 2016). Their amino acid content is going to determine the biological activity of the peptides (Aristoy and Toldrá 2011; Mullen et al. 2017). Due to their amino acid sequences and structural properties, peptides present several biological activities such as antioxidant, antimicrobial, anti-hypertensive (ACE-inhibitory), anticancer, antiviral, antithrombotic, opiate, hypocholesteolemic, immune-modulatory, among the most 
outstanding (Helkar et al. 2016; Lafarga and Hayes 2014), which have influence on the

64 human health (Lemes et al. 2016; Liu et al. 2017; Mullen et al. 2017). Moreover, they can be employed as natural preservatives in foodstuffs and as beneficial constituents in functional foods (Di Bernardini et al. 2011a). In fact, despite the lower activity of the peptides from meat by-products compared to those obtained from synthetic products, some scientific researches discuss the possibility of use them as potential substitute of synthetic products, avoiding the potential toxicity and carcinogenesis of artificial products (Lee et al. 2012a).

\section{Peptides from animal sources}

A wide range of foods and by-products have been employed as source of biopeptides production (Lafarga and Hayes 2017). Among these by-products are included blood (Hu et al. 2016; Adje et al. 2011), bones (Chiang et al. 2019; Gallego et al., 2019; Salazar-Posada et al. 2012), collagen (Ryder et al. 2016; Fu et al. 2015; Saiga et al. 2008), gelatin (Lee et al. 2012a, Herregods. 2010), liver (Verma et al. 2017; Di Bernardini et al. 2011b), lungs (O'Sullivan et al. 2017; Lafarga and Hayes 2017), placenta (Teng et al. 2011), skin (Onuh et al. 2014; Lee et al. 2012b), and visceral mass (Bhaskar et al. 2007).

Collagen is the most abundant protein in multiple by-products obtained from meat industry, and the main component in bones, cartilages, hides and skin (Toldrá et al. 2016). Its partial hydrolysis results in gelatin, a soluble protein compound. Many factors have influence on the properties of the gelatins, such as the species and the age of the animal used (GómezGuillén et al. 2011). Elastin and keratin are other important fibrous structural proteins, which are part of connective tissues, feathers, hair, ligaments and skin (Ferraro et al. 2016). The peptides obtained can be used as food additives since they have a protective effect against lipid oxidation (Di Bernardini et al. 2011a).

Blood is an excellent reservoir of proteins where the most abundant complex is hemoglobin, an iron rich protein (Toldrá et al. 2016). Plasma is obtained by the addition of 
anticoagulants, such as heparin or EDTA, to prevent blood clotting (Böttger et al. 2017). This

89 portion of blood has a great interest due to its functional properties and its absence of color 90 (Jayathilakan et al. 2012).

Most of the peptides have been extracted from bovine and porcine sources, nevertheless the appearance of some diseases and the restrictions established by the regulations or by the religions and culture traditions has made that new alternatives are sought (Sarbon et al. 2013). In this way, several authors support the use of poultry by-products (bones, feet and skin) as source of bioactive peptide (Lee et al. 2010; Jayathilakan et al. 2012; Onuh et al. 2014).

\section{Methods of peptide extraction from meat by-products}

The amino acids that are part of the bioactive peptides are usually inactive in their parent protein (Najafian et al. 2014; Sarmadi et al. 2010). To have functional effects they can be released from the protein sequence through enzymatic hydrolysis, microbial fermentation (proteolytic action of microorganisms), or by acid and alkaline chemical hydrolysis (solvent extraction) (Korhonen et al. 2003; Lafarga and Hayes 2014; Mora et al. 2014; Lemes et al. 2016) (Fig. 1). Enzymatic hydrolysis is considered as the most relevant approach to acquire antioxidant peptides from meat protein (Najafian et al. 2014). Moreover, it is important to note that food processing and gastrointestinal digestion can also release these peptides (Arihara and Ohata, 2010; Escudero et al., 2012).

The hydrolysis conditions, type of enzyme utilized, sequence and configuration of the peptides and the amino acid composition are closely related to the activities of the protein hydrolysates, such as antimicrobial and antioxidant capacities that confer the main impact on the bioactivity (Bah et al. 2015; Wang et al. 2018; Vieira et al. 2017).

\section{Conventional extraction methods}

Enzymatic hydrolysis 
Enzymatic treatment is an attractive method to extract proteins since it employs soft

procedure conditions, the control of reaction is not difficult, and the generation of by-products is minimal (Liu et al. 2010a). It is the most explored and common technique in literature due to its high grade of hydrolysis. In the bioactive peptide isolation, the success and effectiveness of the breakdown of the proteins depend on the conditions of the experiment, the raw material and the type of the enzyme (Table 1). The $\mathrm{pH}$, temperature and time of the process must be fixed and controlled to ensure the final result. Researchers usually work with meat from farm origin due to their accessibility to raw materials and as well as with poultry, porcine and bovine due to their easy market introduction. Although, other kinds of products like venison (Bah et al. 2015; Kim et al. 2016) or buffalo (Liu et al. 2010b) have been studied as result of the new worldwide requirements. The enzymes used have three possible origins: animal, vegetable and microbial (Toldrá et al., 2018). The main peptidases used are papain (cysteine protease from papaya fruit), bromelain (sulfhydryl protease from pineapple fruit), thermolysin (metalloprotease from the bacteria Bacillus thermoproteolyticus), alcalase (serine proteinase from bacteria Bacillus licheniformis) (Mora et al. 2014), flavourzyme (mixture of proteases from the fungus Aspergillus oryzae) (Feng et al. 2014), pepsin and trypsin (enzymes secreted by the stomach and the pancreas of animals, respectively) (Wen et al. 2015).

\section{Acid and alkaline hydrolysis}

Currently, most research lines are focused on the enzymatic hydrolysis due to their effectiveness of breaking down the structure of proteins and the amount of enzymes available. However, the complexity and the cost of them are higher than other methods (like acid and alkaline hydrolysis). The most common acid hydrolysis treatment for proteins is carried out 134 with $\mathrm{HCl}$ and with other sulfonic acids, like methanesulfonic and mercaptoethanesulfonic 135 acids (Fountoulakis et al. 1998), that are taken as a reference to be compared with other treatments like sub-critical water hydrolysis (Rogalinski et al. 2005). On the other hand, the 
most frequent alkaline hydrolysis is the $\mathrm{NaOH}$ treatment, although the $\mathrm{KOH}$ is very usual as well. Peptide bonds are cleaved during the alkaline hydrolysis and, depending on the base used, low molecular weight peptides and sodium and potassium salts of free amino acids are formed (Kalambura et al. 2016). These methods have been used in some animal by-products as porcine blood (Álvarez et al. 2013) and chicken feathers, where the use of microwave treatment supposes a reduction in the hydrolysis time (Lee et al. 2016).

\section{Microbial fermentation}

Another possible source of bioactive peptides is that results from the natural metabolism 145 of bacteria, where their own enzymes release peptides, because they need these proteins as a 146 source of nitrogen, which is essential in their lives. Most of the bioactive peptides isolated by 147 microbial fermentation have been obtained from milk (Aguilar-Toalá et al. 2017), eggs 148 (Nimalaratne et al. 2015) and its derivatives like casein in the case of milk. Lactobacillus are 149 the most common bacteria used due to its greater proteolytic activity (Raveschot et al. 2018). 150 However, this activity is not enough to apply in meat fermentations. As a result, bioactive 151 peptides have barely been isolated from muscle proteins and by-products by this method, 152 perhaps because of the poor proteolytic activity of the Lactobacillus used (Arihara, 2006; 153 Ryan et al. 2011). The lack of literature shows the need to focus the future research in this 154 regard. Even though, Lactobacillus are usually used in the microbial proteolysis, other 155 bacteria have also been studied over the years (Da Silva 2017) in Chryseobacterium with 156 chicken feathers (Fontoura et al. 2014) and Monascus purpureus in porcine liver (Yu et al. 157 2017). The results obtained with the last one strain showed that despite achieving a lower 158 extraction yields compared to those obtained with an enzymatic hydrolysis, the antioxidant 159 activity of the extracted compounds was higher.

\section{Non-conventional extraction methods}

Sub-critical water hydrolysis 
Other technique used for the extraction of proteins is sub-critical water hydrolysis (SWH). This extraction uses water as solvent in sub-critical state, from $100{ }^{\circ} \mathrm{C}$ to $374{ }^{\circ} \mathrm{C}$ at $0.10 \mathrm{MPa}$ and $22 \mathrm{MPa}$, respectively. In the sub-critical state, water has the ability to extract ionic and polar compounds as well as non-polar compounds, leading to the hydrolysis and the breakdown of the protein structure, thus releasing the peptides. Moreover, if the extraction time is increased, it allows the extraction of amino acids. Some researchers have been used this technique for the extraction of peptides from meat by-products (Esteban et al. 2010; Zhu et al. 2010; Álvarez et al. 2012). Álvarez et al. (2012) managed to improve the antioxidant and functional characteristics of the peptides extracted from porcine hemoglobin. The peptides obtained were more soluble and had higher reducing antioxidant power, while a double-step enzymatic hydrolysis would be needed to achieve the same results (Chang et al. 2007). Moreover, the extraction yields obtained were high, obtaining values up to $80 \%$ with conditions of time and temperature of 360 minutes and $180{ }^{\circ} \mathrm{C}$. Despite being cheap and clean (not use solvents, so it can be considered as green technology), this extraction can lead to modifications in the structure of the proteins that suppose the loss of their techno functional properties (Lynch et al. 2018; Drummond et al. 2019).

\section{Isoelectric solubilization/precipitation}

Other emerging technology is the isoelectric solubilization/precipitation (ISP) that allow to recover the protein in several steps through changes of $\mathrm{pH}$. The process involves a solubilization of the protein in an alkaline medium, a purification and concentration using a membrane technology with a $\mathrm{pH}$ adjustment, to finally centrifuge and thus get an isoelectric precipitation (Tahergorabi et al. 2011). The yield of this extraction will depend on both the material from which the extraction is made and the extraction conditions $(\mathrm{pH}$, temperature, extraction time) (Selmane et al. 2008).

\section{Emerging technologies as pretreatment of meat by-products}


There is not much information about the extraction methods of hydrolyzed peptides

from meat by-products, being the aforementioned methods those commonly used. However, others can also be applied as alternative techniques to support the extraction procedures of peptides. This is the case of microwave processing that is also used as pretreatment in the chemical alkali and acid hydrolysis of chicken feathers (Lee et al. 2016) and sheep skin (Gousterova et al. 2005).

Recently, in order to avoid the alteration of the functional properties of these proteins, alternative methods are being carried out (Lynch et al. 2018). It is about emerging technologies which avoid using high temperatures and reduce the use of solvents. Between these processing techniques are high hydrostatic pressures, pulsed electric fields, and ultrasounds (Mullen et al. 2017). Pulsed electric fields (PEF) and ultrasounds (US) are considered emerging non-thermal technologies, since in this case heat comes from internal energy generation (Tahergorabi and Hosseini 2017), thus reducing the temperature effects on peptides (cross bonds, peptide breakdown, protein denaturation) (Korhonen et al. 1998). Despite not having much information about the applicability of PEF on the extraction of 202 peptides from meat by-products, some studies suggested its potential use (Gudmundsson and 203 Hafsteinsson 2001). In this way, Ghosh et al. (2019) used this non-thermal technology for the extraction of proteins from waste chicken meat. The application of high voltage, short pulses followed by low voltage, long pulses result on chemical-free extracts with potential antioxidant properties (Gómez et al. 2019).

High pressure processing technology (HPP) can be considered as an alternative to thermal processes since it employs pressures in the range $400-700 \mathrm{MPa}$ at refrigerated to moderate temperatures (under $50{ }^{\circ} \mathrm{C}$ ) (Escobeda-Avellaneda et al. 2011). Some researchers have evaluated it as a pretreatment to the extraction of peptides from meat by-products 
211 (Toldrá et al. 2011). The results obtained allow through the changes in the structure of protein

to improve the enzymatic hydrolysis and decrease the incubation period.

Ultrasound technique allows through cavitation, wherein microbubbles are formed, grow in size and eventually collapse due to propagation of ultrasounds in the biological matrix (Kadam et al. 2015). This method is faster, and its results show a smaller molecular weight and higher peptide concentrations in porcine cerebral hydrolysate (Zou et al. 2016). Moreover, its combination with enzymatic hydrolysis favors the hydrolysis yields and the antioxidant activity of the peptides obtained (Vidal et al. 2018a,b).

\section{Purification of protein hydrolysates}

Once the protein hydrolysate is obtained, it is advisable to carry out a fractionation and purification of the mixture of peptides (Agyei and Danquah 2011; Lafarga and Hayes 2014) (Fig. 1). This is a critical step that suppose percentages up to $70 \%$ of the peptide production costs (Agyei and Danquah 2011). It is possible isolate the hydrolysates obtained depending on their molecular weight using ultrafiltration with molecular-weight cut-off (MWCO) membranes (Korhonen et al. 2003; Sohaib et al. 2017; Power et al. 2014). The smaller molecular weights of the peptides, the greater the antioxidant activity (Lee et al. 2016). Therefore, a purification process is necessary to introduce them as bioactive substances in food or pharmaceutical products. Size exclusion chromatography (SEC), ionic 229 chromatography (IC) and high-performance liquid chromatography (HPLC) are the three most common techniques used in this stage (Korhonen et al. 2003; Mullen et al. 2017). The last mentioned could be considered the most important due to its high ability to separate biopeptides (Sohaib et al. 2017).

\section{Bioactive peptides as natural antioxidants}

Antioxidants can be natural or synthetic substances with the ability to inhibit or delay oxidative cell damage on oxidizable substrates at relatively low concentrations (Apak et al. 
2016). The action of antioxidants positively affects the shelf life and the quality of meat

237 products, since they delay the lipid oxidation and reduce rancidity without modifying negatively their nutritional or sensory properties (Kumar et al. 2015). Many synthetic chemical antioxidants have been recognized, such as tert-Butylhydroquinone (TBHQ), butylated hydroxytoluene (BHT), butylated hydroxyanisole (BHA) and propyl gallate (PG) that have a strong antioxidant activity as food additives. They prevent the deterioration and were extensively applied to extend the shelf life of food (Guo et al. 2015). Nevertheless, they also have unfavorable consequences on DNA and human enzyme system (Liu et al. 2016), so their use should be under stringent limitation (Yang et al. 2018). Thus, natural antioxidants are becoming importance in the meat industry because of the non-acceptance of the customers over the synthetics antioxidants (Kumar et al. 2015).

The antioxidant importance of peptides was the focus of several researches (Di Bernardini et al. 2011a; Lorenzo et al. 2018). They allow to reduce the oxidative degradation, since they react quickly with the reactive oxygen species (Chakka et al. 2015; Liu et al. 2016). These free radicals, highly chemically reactive, can react spontaneously with cellular components and harm proteins, lipids and DNA (Gupta et al. 2019). They play a critical role causing serious disorders like cancer and cardiovascular diseases (Teng et al. 2011). Also, they can cause damage tissues or cells and lead to aging, coronary heart affections, inflammation, stroke and diabetes mellitus (Ye et al. 2018). Radicals can be deactivated employing antioxidants that act through two major mechanisms, hydrogen atom transfer (HAT) and single electron transfer (ET) (Lorenzo et al. 2018). It must be emphasized that the antioxidant action is a multiple chemical reaction where sometimes many complex mechanisms take part (Li et al. 2018).

There are many antioxidant peptides reported in meat products like dry-cured hams (Escudero, Aristoy, Nishimura, Arihara, \& Toldrá, 2012; Mora, Escudero, \& Toldrá, 2016). 
In Spanish dry-cured ham, peptides SAGNPN and GLAGA exerted very high antioxidant

262 activity and reducing power, respectively (Escudero, Mora, Fraser, Aristoy, \& Toldrá, 2013), peptide SNAAC had an IC50 of $75.2 \mu \mathrm{M}$ for DPPH assay and $205 \mu \mathrm{M}$ in reducing power (Mora, Escudero, Fraser, Aristoy \& Toldrá, 2014) and was stable against heating and gastrointestinal digestion (Gallego, Mora \& Toldrá, 2018a). On the contrary, peptide AEEEYPDL that was also a powerful antioxidant peptide but was cleaved by pepsin during the gastrointestinal digestion (Gallego, Mora \& Toldrá, 2018b).

Total antioxidant capacity (TAC) measurement methods are commonly noncompetitive 269 electron transfer (ET) and mixed-mode (ET/HAT) assays (usually involving a redox reaction 270 with the oxidant). The ferric reducing antioxidant power (FRAP) mechanism is completely 271 electron transfer rather than mixed ET/HAT, so in combination with other methods can be 272 very useful in discerning dominant mechanisms with distinct antioxidants. Copper reduction 273 (CUPRAC) assay is a variant of the FRAP assay, it uses copper instead of iron, so it is also included in ET methods (Prior et al. 2005). Despite the 2,2'-azino-bis (3-ethylbenzothiazoline6-sulphonic acid) (ABTS), trolox equivalent antioxidant capacity and 2,2-diphenyl-1picrylhydrazyl (DPPH) assessments are generally categorizes as ET reactions. These two radicals may be deactivated either by direct reduction through ET mechanism or by radical quenching via HAT. In contrast, antioxidant activity (AOA) assays, oxygen radical absorbance capacity (ORAC), total radical-trapping antioxidant parameter (TRAP), and total oxyradical scavenging capacity (TOSC) are normally competitive and work on HAT mechanism (Apak et al. 2016).

The use of various antioxidant methods helps to understand which type or types of mechanisms are involved in the activity of peptides, although the lack of standardization complicates the comparison between assays (Lorenzo et al. 2018; Huang et al. 2005). Among the diverse methods employed to determine the antioxidant capacity (Fig. 2), the most widely 
used are 2,2-diphenyl-1-picrylhydrazyl (DPPH), 2,2'-azino-bis (3-ethylbenzothiazoline-6sulphonic acid) (ABTS), metal chelating activity (MCA), reducing antioxidant power (FRAP), oxygen radical absorbance capacity (ORAC) and hydroxyl and superoxide anion radical scavenging activity (Lorenzo et al. 2018).

\section{Noncellular antioxidant activity}

The hydrolysates obtained from the enzymatic hydrolysis of skin by-products displayed antioxidant properties (Table 1). The gelatin hydrolysates obtained stand out for their emulsifying, foaming and gelling properties with important applications in cosmetic, food and pharmaceutical fields (Sarbon et al. 2013). As mentioned before, the enzymes used for their extraction is going to condition their activity, being pepsin and its combination with collagenase which showed the hydrolysate with the highest free radical scavenging activity (Lee et al. 2012a,b). Li et al. (2007) also found that the combination of proteases from bovine pancreas and from Streptomyces and Bacillus polymyxa resulted in higher antioxidant values.

In contrast, Onuh et al. (2014) found that alcalase showed higher antioxidant capacity than those found by the mixture of pepsin and pancreatin (35\% vs $33 \%, 95 \%$ vs $80 \%$, and $3800 \mu \mathrm{M}$ Trolox equivalent/g vs $3200 \mu \mathrm{M}$ Trolox equivalent/g for DPPH, metal chelating effect and ORAC, respectively). These results could be related with the fact that different sources of chicken skin (breast and thigh hydrolyzed with pepsin and pancreatin or alcalase, respectively) were used for these extractions.

Other source of bioactive peptides is bovine lung (O’Sullivan et al. 2017a). It hydrolysis with Alcalase, papain and pepsin results in hydrolysates with antioxidant activity. FRAP assay showed low ferric reducing activity power in the lung hydrolysates. The values were approximately $6 \mu \mathrm{M} \mathrm{Fe}$ papain and pepsin hydrolysates, respectively. Within ORAC determination, papain and pepsin 
hydrolysates showed similar values (400 $\mu$ mol Trolox equivalents), while Alcalase displayed the highest values (around $450 \mu \mathrm{mol}$ Trolox equivalents).

Liver is an important source of peptides. Di Bernardini et al. (2011b) demonstrated the antioxidant activity of the peptidic fractions obtained from bovine liver. Thermolysin was the enzyme used in the hydrolysis of sarcoplasmic proteins. DPPH, FRAP and $\mathrm{Fe}^{2+}$ chelating ability assays were utilized to evaluate their in vitro antioxidant activity. FRAP showed similar activity in the three types of hydrolysates studied with values of $8.78,8.37$ and 9.37 $\mu \mathrm{g}$ Trolox equivalents/mg for non-ultrafiltered, ultrafiltered 10-kDa MWCO and ultrafiltered 3-kDa MWCO hydrolysates, respectively. Within DPPH, non-ultrafiltered samples displayed the highest scavenging activity (84.09\% vs $83.89 \%$ and $82.24 \%$ for non-ultrafiltered, ultrafiltered $10-\mathrm{kDa}$ and ultrafiltered $3-\mathrm{kDa}$ samples, respectively). On the contrary, ultrafiltered samples displayed the highest metal chelating ability $(67.36 \%$ and $60.59 \%$ vs $55.57 \%$ for ultrafiltered 10-kDa and 3-kDa vs non-ultrafiltered samples, respectively).

Alcalase, papain and trypsin were also used for the extraction of hydrolysates from porcine liver (Verma et al. 2017). The samples hydrolyzed with trypsin displayed the highest antioxidant activity in the three assays studied. ABTS radical scavenging activity showed values of $86.8 \%$, while the samples obtained with Alcalase and papain displayed values lower than $75 \%$. The highest values of trypsin could be related with the degree of hydrolysis achieved with trypsin $(26.82 \%$ vs $23.56 \%$ and $19.12 \%$ for trypsin vs Alcalase and papain, respectively), since it could be considered as one of the factors that has influence on the ability of hydrolysates to eliminate $\mathrm{ABTS}^{+}$radicals (Phanturat et al. 2010). In all cases FRAP values were above $12 \mathrm{mM}$ equivalent to $\mathrm{FeSO}_{4} \cdot 7 \mathrm{H}_{2} \mathrm{O}$. The different values obtained for this method could be related with the type of proteinase used, since the higher reducing power observed in trypsin hydrolysates could be associated with the smallest size peptides obtained from the hydrolysis (Ajibola et al. 2011). In DPPH radical scavenging activity, trypsin 
335

hydrolysates presented values of $57.5 \%$, whereas in Alcalase and papain hydrolysates the values were below 50\%. Yu et al. (2017) observed a similar DPPH radical scavenging activity in porcine liver proteins hydrolyzed with Alcalase and papain (42\% and 37\%, respectively), while the hydrolysates obtained with pepsin showed the highest values, similar than those obtained for the aforementioned authors (55\% vs 57.5\%). Chou et al. (2014) evaluated the antioxidant ability of chicken liver hydrolysates obtained by hydrolysis with pepsin. The results obtained showed a higher DPPH ability than those obtained with the same enzyme in porcine liver. However, similar values were obtained for the chelating ability of ferrous ion (about 90\%).

In addition to the known antioxidant activity of the liver, Damgaard et al. (2014) demonstrate that porcine by-products as appendix, colon, heart, liver, lung, pancreas and rectum can also generate antioxidant hydrolysates. Appendix $(77.0 \%, 84.4 \%$ and $17.1 \%$ for FRAP, ABTS and DPPH, respectively) and colon (79.3\%, 86.4\% and 17.6\% for FRAP, 348 ABTS and DPPH, respectively) showed the highest antioxidant capacity, only surpassed by 349 liver in FRAP, lung in ABTS and heart in DPPH. Similar results were also found by 350 Damgaard et al. (2015), who confirmed that hydrolysates obtained from porcine (colon, heart 351 and neck) and bovine (lung, kidney and pancreas) tissues displayed antioxidant activity. In 352 this case, bovine kidney and lung showed the higher ion chelation $(63.4 \%$ and $55.0 \%$, 353 respectively), while porcine colon and heart presented the higher ABTS values (49.6\% and $35444.6 \%$, respectively).

356 extraction of the hydrolysates was carried out though an autolytic degradation of protein of 357 connective tissues, gall bladder, intestine and spleen. Hydrolysates showed higher values than 358 those obtained in peptide fractions $(<3 \mathrm{kDa}, 3-10 \mathrm{kDa},>10 \mathrm{kDa})$ in all of the radical 
scavenging activity assays $(721.6 \mu \mathrm{M}$ TEAC/mg, $244.2 \mu \mathrm{M}$ TEAC/mg, $47.0 \%$ and $43.9 \%$ for ABTS, DPPH, Hydroxyl and Superoxide radical scavenging activity, respectively).

Besides to viscera, there are other duck processing by-products such as feet, bones and heads that have been evaluated as a source of valuable bioactive compounds (Lee et al. 2010). In this study, eight proteases (Alcalase, $\alpha$-chymotrypsin, flavourzyme, neutrase, papain, pepsin, protamex and trypsin) were used to isolate antioxidant peptides. The hydroxyl radical scavenging activity of the obtained enzymatic hydrolysates displayed $\mathrm{IC}_{50}$ values of 571 $\mathrm{mg} / \mathrm{mL}$. Lee et al. (2012b) obtained similar values when these enzymes were used in duck skin by-products $(554 \mu \mathrm{g} / \mathrm{mL})$.

Recent results also showed the potential of dry-cured ham bones as a source of antioxidant peptides that retain their bioactivity after household cooking preparations and gastrointestinal digestion. In fact, cooking using conventional household methods increased the antioxidant activity of ham by-products whereas simulated gastrointestinal digestion showed no significant effect on the antioxidant activity of ham by-products and antioxidant activity decreased when assessed using the ORAC and $\beta$-carotene bleaching assays. In this study, collagen peptides were responsible for the differences in antioxidant activities observed in cooked samples after simulated gastrointestinal digestion. This fact confirmed the traditional believe of bioactive properties of bone broths and stews (Gallego et al. 2017).

Blood is other edible by-product considered as a source of bioactive compounds due to its important protein contents (Bah et al. 2013). It is composed by two fractions: cellular (hemoglobin) and plasma (immunoglobulins, fibrinogen and serum albumin). Hydrolysates with significant antioxidant activity were found in bovine blood (O’Sullivan et al. 2017b). Papain was used for the hydrolysis of the blood protein fractions $(\alpha / \beta$-globulins, serum albumin, $\gamma$-globulins and fibrinogen). $\gamma$-globulin and fibrinogen hydrolysates were those that showed the highest activity. The values of fibrinogen were around $25 \mu \mathrm{M} \mathrm{Fe} / 2 / \mathrm{mg} / \mathrm{mL}$ in 
FRAP assay and $1000 \mu \mathrm{mol}$ Trolox equivalents in ORAC determination. $\gamma$-globulin displayed an intermediate activity with values around $17 \mu \mathrm{M} \mathrm{Fe} \mathrm{Fe}^{+2} / \mathrm{mg} / \mathrm{mL}$ and $800 \mu \mathrm{mol}$ Trolox equivalents for FRAP and ORAC assays, respectively. Finally, $\alpha / \beta$-globulins showed the lowest values both in FRAP and ORAC assays (less than $5 \mu \mathrm{M} \mathrm{Fe}$ $\mu \mathrm{mol}$ Trolox equivalents, respectively).

The hydrolysates isolated from plasma has several properties, highlighting its antioxidant activity (Liu et al. 2010a,b; Adje et al. 2011; Nyberg et al. 2013). Bah et al. (2015) also claimed that plasma of deer, sheep and pig allow to obtain bioactive peptides and peptide-rich protein hydrolysates. Their antioxidant activity was tested through DPPH, FRAP and ORAC assays. The hydrolysates obtained with the use of proteases from fungal displayed higher DPPH values than those found with other enzymes from plants (papain and bromelain). The hydrolysates obtained from pig plasma with fungal enzymes also displayed higher DPPH (55.2\%) activities than those found in other porcine plasma hydrolysates obtained using pepsin (48.4\%) and trypsin (11.5\%) (Wei and Chiang 2009; Xu et al. 2009), but lower than those obtained with Alcalase (76.5\%; Liu et al. 2010a). A similar behavior was observed with FRAP and ORAC essays. Higher capacity was obtained with fungal proteases and in deer and sheep plasma hydrolysates. This could be due to these fungal enzymes are capable of producing small peptides associated with highest antioxidant properties (Di Pierro et al. 2014).

\section{Cellular antioxidant activity}

In vivo determinations are necessary to evaluate bioavailability and functionality of antioxidant peptides. These assays could be due through cell or animal models. Both models allow to know more information about the metabolism of these antioxidant compounds (Liu et al. 2016). The cellular antioxidant activity of the hydrolysates could be tested though the comet assay. This method, based on the method described by Phelan et al. (2009), allows to 
evaluate the potential ability of hydrolysates to preserve the cells from DNA damage. This harm could be due to the reaction between free radicals and cellular components (Gupta et al., 2019). In this procedure, U937 lymphocytes cells were incubated with hydrolysates for 24 hours to then start the cell damage with $\mathrm{H}_{2} \mathrm{O}_{2}$ for 30 minutes at $37{ }^{\circ} \mathrm{C}$. The results can be expressed as tail DNA damage or as a relative percentage to $\mathrm{H}_{2} \mathrm{O}_{2}$ control values. The last ones were conducted in order to know the concentration needed to produce a significant DNA damage. Some researchers have been used this assay in hydrolysates obtained from meat byproducts. O’Sullivan et al. (2017a,b) evaluated the cellular antioxidant activity of bovine lung and blood hydrolysates. These hydrolysates did not display ability to prevent DNA damage. In contrast, peptides obtained from buffalo horn showed protection against the damage of rat cerebral cells (Liu et al. 2010b). Other studies were carried out in rat liver cells (Ac2F) to evaluate the effect that the presence or the absence of peptides has on cell viability (Kim et al. 2001). The MTT method (role of mitochondrial succinate dehydrogenase) will allow to ascertain the possible mechanisms of non-enzymatic cellular defence induced by these compounds.

Animal models assess the bioavailability of antioxidant peptides through different methods such as enzymatic defence catalase (CAT), superoxide dismutase (SOD) and glutathione peroxidase (GPx) (Liu et al. 2016). The toxicity studies are usually carried out using Wistar rats and the bioactive compounds are determined in the gastrointestinal tract, liver and kidney (Lee et al. 2012b).

\section{Antimicrobial activity of bioactive peptides}

Conventional antibiotics have been used for a long time due to their active properties; 431 however, the emergence of resistance to them has led to seek new sources (Lafarga and Hayes 432 2014). Peptides could meet this demand since there are studies that assert that they are able to 433 inhibit the action of strains of pathogenic and altering microorganisms (Table 2) such as 
Gram-positive (Listeria monocytogenes, Bacillus cereus, Staphylococcus aureus, Micrococcus luteus) and Gram-negative (Escherichia coli, Yersinia enterocolitica) (Adje et al. 2011; Di Bernardini et al. 2011a). The highest antibacterial activity was observed when the molecular weight of these peptide hydrolysates was between 400 and 1400 Da (Ryan et al. 2011). Moreover, some authors confirmed that a $\alpha$-helical conformation favors their action against microorganisms (Daoud et al. 2005). In fact, an antibacterial peptide was obtained from a fragment of the $\alpha$-chain of bovine hemoglobin. This peptide had activity against Escherichia coli, Listeria innocua, Micrococcus luteus and Salmonella enteritidis. Similar results were also obtained by Nedjar-Arroume et al. (2006). Another peptide RHGYM, isolated from dry-cured ham, was able to inhibit the growth of L. monocytogenes, showing a MIC value of $6.25 \mathrm{mM}$ (Castellano et al. 2016).

The commonly method used to evaluate this activity is the disk diffusion method (Kirby-Bauer method). It is a technique based on the method described by Bauer et al. (1966), which consists on the relationship between the concentration of the substance necessary to inhibit a bacterial strain and the inhibition halo of growth on the surface of an agar plate with a suitable culture medium and seeded homogeneously with the bacteria to be tested (Fig. 2). As a positive control for gram-positive bacteria could be used Nisin and Gentamicin as a positive control against gram-negative bacteria.

Many researchers have tested the antibacterial activity of protein hydrolysates. Chakka et al. (2015) found that the hydrolysates obtained from the enzymatic hydrolysis of chicken liver only displayed a moderate inhibition against Micrococcus luteus $(12 \mathrm{~mm})$. Whereas, hydrolysates obtained from porcine liver with Alcalase, papain and trypsin showed antimicrobial activity against Bacillus cereus, Escherichia coli, Listeria monocytogenes and Staphylococcus aureus. As it happened with the antioxidant activity, trypsin hydrolysates displayed the highest antimicrobial activity in all of the strains evaluated. These results could 
459 be due to the influence that the degree of hydrolysis had in the antimicrobial activity and the 460 hydrophobic and cationic properties of the peptides obtained. These abilities allow to modify 461 the permeability of microbial membranes leading to their breakdown. Moreover, the smaller size peptides obtained from the hydrolysis with trypsin would favor the interaction with the microbial membrane (Verma et al. 2017).

No antimicrobial activity was found by Bah et al. (2015) in the hydrolysates obtained from deer, pig, and sheep plasma with plant and fungal proteases against strains usually found in meat (E. coli, Pseudomonas aeruginosa and Staphylococcus aureus). A possible explanation for this behavior could be related to the fact that the enzymes used are not able to extract peptides from the plasma proteins with this ability. In this way, alternative hydrolysis methods were developed in order to obtain peptides with antibacterial properties. These methods consist in limiting the hydrolysis using an alcohol, which results in a modification of the protein conformation. Adje et al. (2011) studied this controlled hydrolysis using several alcohols (butanol, ethanol, methanol or propanol) and pepsin. The results obtained were satisfactory since it was possible to isolate antimicrobial peptides. These compounds were effective against Escherichia coli, Listeria innocua and Micrococcus luteus. In his case, the activity of the peptides was calculated through the minimum inhibitory concentration (MIC), that allow to know the minimum concentration enough to completely inhibited the microbial growth on agar plates after 24 hours at $37^{\circ} \mathrm{C}$ (Froidevaux et al. 2001).

\section{Conclusions}

Slaughtered by-products are an important source of novel bioactive compounds, what makes them become into products with a great added-value with the consequent positive economic impact for meat sector and environmental benefits. The hydrolysates extracted from these waste materials have the potential to be a protein rich ingredient for use in formulated food products and possible help in reduction of oxidative and microbial deterioration, since 
the antimicrobial and antioxidant properties associated with these peptides would allow to extend the shelf life of food, even improving the results obtained with synthetic products. The results of noncellular antioxidant activity are validated by in vivo models, which allow to evaluate their toxicity, bioaccessibility and bioavailability, and above all their safety for their use. The pretreatment with emerging technologies would increase the quality of these compounds since they hardly affect the composition and the structure of these hydrolysate compounds, increasing the extraction yields as well as their antioxidant properties. In this way, the combination of HPP, PEF or US with enzymatic hydrolysis is effective as it improves the hydrolysis yields and the antioxidant activity of the peptides obtained. Finally, besides bovine and porcine sources, this review confirms the possibility of use poultry byproducts as valuable bioactive peptides resource.

\section{Compliance with Ethical Standards}

\section{Funding}

This research was supported by Grant RTA 2017-00024-CO4-04 from INIA (Spain) and Grant AGL2017-89381-R from Spanish Ministry of Economy, Industry and Competitiveness and Fondo Europeo de Desarrollo Regional (FEDER). Acknowledgments to INIA for granting Paula Borrajo with a predoctoral scholarship (grant number CPD2016-0030). LM was supported by Ramón y Cajal postdoctoral contract. José M. Lorenzo is member of the HealthyMeat network, funded by CYTED (ref. 119RT0568). Thanks to GAIN (Axencia Galega de Innovación) for supporting this research (grant number IN607A2019/01).

\section{Conflict of Interest}

Paula Borrajo declares that she has no conflict of interest. Mirian Pateiro declares that 506 she has no conflict of interest. Francisco J. Barba declares that he has no conflict of interest. 507 Leticia Mora declares that she has no conflict of interest. Daniel Franco declares that he has 
no conflict of interest. Fidel Toldrá declares that he has no conflict of interest. José M. Lorenzo declares that he has no conflict of interest.

\section{Ethical Approval}

This article does not contain any studies with human or animal subjects.

\section{Informed consent}

Not applicable.

\section{References}

Adje EY, Balti R, Kouach M, Dhulster P, Guillochon D, Nedjar-Arroume N (2011) Obtaining antimicrobial peptides by controlled peptic hydrolysis of bovine hemoglobin. Int J Biol Macromol 49(2):143-153.

Aguilar-Toalá JE, Santiago-López L, Peres CM, Peres C, Garcia HS, Vallejo-Cordoba B, Hernández-Mendoza A (2017) Assessment of multifunctional activity of bioactive peptides derived from fermented milk by specific Lactobacillus plantarum strains. J Dairy Sci 100(1):65-75.

Agyei D, Danquah MK (2011) Industrial-scale manufacturing of pharmaceutical-grade bioactive peptides. Biotechnol Adv 29(3):272-277.

Ajibola CF, Fashakin JB, Fagbemi TN, Aluko RE (2011) Effect of peptide size on antioxidant properties of African yam bean seed (Sphenostylis stenocarpa) protein hydrolysate fractions. Int J Mol Sci 12:6685-6702.

Apak R, Özyürek M, Güçlü K, Çapanoğlu E (2016) Antioxidant activity/capacity measurement. 1. Classification, physicochemical principles, mechanisms, and electron transfer (ET)-based assays. J Agric Food Chem 64(5):997-1027.

Álvarez C, Rendueles M, Diaz M (2012) Production of porcine hemoglobin peptides at moderate temperature and medium pressure under a nitrogen stream. Functional and antioxidant properties. J Agric Food Chem 60:5636-5643.

Álvarez C, Rendueles M, Díaz M (2013) Alkaline hydrolysis of porcine blood haemoglobin: 533 applications for peptide and amino acid production. Anim Prod Sci 53(2):121-128. 
229.

Arihara K, Ohata M (2010) Functional meat products. In: Toldrá F (ed) Handbook of meat processing. Wiley-Blackwell, Ames, Iowa, pp 423-439.

Aristoy MC, Toldrá F (2011) Essential amino acids. In: Nollet LML, Toldrá F (eds) Handbook of analysis of edible animal by-products. CRC Press, Boca Raton, FL, USA, pp 123-136.

Bah CS, Bekhit AEDA, Carne A, McConnell MA (2013) Slaughterhouse blood: an emerging source of bioactive compounds. Compr Rev Food Sci Food Saf 12(3):314-331.

Bah CS, Bekhit AEDA, Carne A, McConnell MA (2015) Production of bioactive peptide hydrolysates from deer, sheep and pig plasma using plant and fungal protease preparations. Food Chem 176:54-63.

Bauer AW, Kirby WMM, Sherris JC, Turck M (1966) Antibiotic susceptibility testing by a standardized single disk method. Am J Clin Pathol 45:493-496.

Bhaskar N, Modi VK, Govindaraju K, Radha C, Lalitha RG (2007) Utilization of meat industry by products: protein hydrolysate from sheep visceral mass. Bioresour Technol 98(2):388-394.

Böttger R, Hoffmann R, Knappe D (2017) Differential stability of therapeutic peptides with different proteolytic cleavage sites in blood, plasma and serum. PloS One 12(6):e0178943.

Castellano, P., Mora, L., Escudero, E., Vignolo, G., Aznar, R., Toldrá, F. (2016) Antilisterial peptides from Spanish dry-cured hams: purification and identification. Food Microb 59: 133-141.

Chakka AK, Elias M, Jini R, Sakhare PZ, Bhaskar N (2015) In-vitro antioxidant and antibacterial properties of fermentatively and enzymatically prepared chicken liver protein hydrolysates. J Food Sci Technol 52(12):8059-8067.

Chang CY, Wu KC, Chiang SH (2007) Antioxidant properties and protein compositions of porcine haemoglobin hydrolysates. Food Chem 100:1537-1543.

Chiang JH, Loveday SM, Hardacre AK, Parker ME (2019) Effects of enzymatic hydrolysis treatments on the physicochemical properties of beef bone extract using endo- and exoproteases. Int J Food Sci Technol 54(1):111-120. 
Chou CH, Wang SY, Lin YT, Chen YC (2014) Antioxidant activities of chicken liver

hydrolysates by pepsin treatment. Int J Food Sci Technol 49(7):1654-1662.

Da Silva RR (2017) Bacterial and fungal proteolytic enzymes: production, catalysis and potential applications. Appl Biochem Biotechnol 183(1):1-19.

Damgaard TD, Otte JA, Meinert L, Jensen K, Lametsch R (2014) Antioxidant capacity of hydrolyzed porcine tissues. Food Sci Nutr 2(3):282-288.

Damgaard T, Lametsch R, Otte J (2015) Antioxidant capacity of hydrolyzed animal by-products and relation to amino acid composition and peptide size distribution. J Food Sci Technol 52(10):65116519.

Daoud R, Dubois V, Bors-Dodita L, Nedjar-Arroume N, Krier F, Chihib NE, Guillochon D (2005) New antibacterial peptide derived from bovine hemoglobin. Peptides 26(5):713-719.

Di Bernardini R, Harnedy P, Bolton D, Kerry J, O'Neill E, Mullen AM, Hayes M (2011a) Antioxidant and antimicrobial peptidic hydrolysates from muscle protein sources and by-products. Food Chem 124:1296-1307.

Di Bernardini R, Rai DK, Bolton D, Kerry J, O'neill E, Mullen AM, Hayes M (2011b) Isolation, purification and characterization of antioxidant peptidic fractions from a bovine liver sarcoplasmic protein thermolysin hydrolyzate. Peptides 32(2):388-400.

Di Pierro G, O’Keeffe MB, Poyarkov A, Lomolino G, FitzGerald RJ (2014) Antioxidant activity of bovine casein hydrolysates produced by Ficus carica L.-derived proteinase. Food Chem 156:305-311.

Drummond L, Álvarez C, Mullen AM (2019) Proteins recovery from meat processing coproducts. In: Galanakis CM (ed) Sustainable meat production and processing. Academic Press, London, United Kingdom, pp 69-83.

Escobedo-Avellaneda Z, Pateiro M, Chotyakul N, Torres JA, Welti-Chanes J, Lamela CP (2011) Benefits and limitations of food processing by high-pressure technologies: effects on functional compounds and abiotic contaminants. CyTA-J Food 9(4):351-364. 
Escudero E, Toldrá F, Sentandreu MA, Nishimura H, Arihara K (2012) Antihypertensive

activity of peptides derived from the in vitro gastrointestinal digestion of pork meat. Meat Sci 91:306311.

Escudero E, Mora L, Fraser P D, Aristoy MC, Toldrá F (2013). Identification of novel antioxidant peptides generated in Spanish dry-cured ham. Food Chem 138(2-3): 1282-1288.

Esteban MB, García AJ, Ramos P, Márquez MC (2010) Sub-critical water hydrolysis of hog hair for amino acid production. Bioresour Technol 101:2472-2476.

FAOSTAT (2016). http://www.fao.org/faostat/en/\#data/QL/metadata.

Feng L, Qiao Y, Zou Y, Huang M, Kang Z, Zhou G (2014) Effect of Flavourzyme on proteolysis, antioxidant capacity and sensory attributes of Chinese sausage. Meat Sci 98(1):34-40.

Ferraro V, Anton M, Santé-Lhoutellier V (2016) The "sisters" $\alpha$-helices of collagen, elastin and keratin recovered from animal by-products: Functionality, bioactivity and trends of application. Trends Food Sci Technol 51:65-75.

Fontoura R, Daroit DJ, Correa AP, Meira SM, Mosquera M, Brandelli A (2014) Production of feather hydrolysates with antioxidant, angiotensin-I converting enzyme-and dipeptidyl peptidase-IVinhibitory activities. N Biotechnol 31(5):506-513.

Fountoulakis M, Lahm HW (1998) Hydrolysis and amino acid composition analysis of proteins. J Chromatogr A 826(2):109-134.

Froidevaux R, Krier F, Nedjar-Arroume N, Vercaigne-Marko D, Kosciarz E, Ruckebusch C, Guillochon D (2001) Antibacterial activity of a pepsin- derived bovine hemoglobin fragment. Febs Letters 491(1-2):159-163.

Fu Y, Young JF, Dalsgaard TK, Therkildsen M (2015) Separation of angiotensin I- converting enzyme inhibitory peptides from bovine connective tissue and their stability towards temperature, $\mathrm{pH}$ and digestive enzymes. Int J Food Sci Technol 50(5):1234-1243.

Gallego M, Mora L, Reig M, Toldrá F (2018a). Stability of the potent antioxidant peptide SNAAC identified from Spanish dry-cured ham. Food Res Int 105:873-879.

Gallego M, Mora L, Toldrá F (2018b). Characterisation of the antioxidant peptide AEEEYPDL and its quantification in Spanish dry-cured ham. Food Chem 258:8-15. 
Gallego M, Mora L, Hayes M, Reig M Toldrá F (2019) Peptides with potential cardioprotective

actions derived from dry-cured ham by-products. J Agric Food Chem 67:1115-1126.

Gallego M, Mora L, Hayes M, Reig M Toldrá F (2017) Effect of cooking and in vitro digestion on the antioxidant activity of drycured ham by-products. Food Res Int 97:296-306

Ghosh S, Gillis A, Sheviryov J, Levkov K, Golberg A (2019) Towards waste meat biorefinery: Extraction of proteins from waste chicken meat with non-thermal pulsed electric fields and mechanical pressing. J Clean Prod 208:220-231.

Gómez B, Munekata PE, Gavahian M, Barba FJ, Martí-Quijal FJ, Bolumar T, Lorenzo JM (2019) Application of pulsed electric fields in meat and fish processing industries: An overview. Food Res Int 123:95-105.

Gómez-Guillén MC, Giménez B, López-Caballero MA, Montero MP (2011) Functional and bioactive properties of collagen and gelatin from alternative sources: A review. Food Hydrocoll 25(8):1813-1827.

Gousterova A, Braikova D, Goshev I, Christov P, Tishinov K, Vasileva- Tonkova E, Nedkov P (2005) Degradation of keratin and collagen containing wastes by newly isolated thermoactinomycetes or by alkaline hydrolysis. Lett Appl Microbiol 40(5):335-340.

Gudmundsson M, Hafsteinsson H (2001) Effect of electric field pulses on microstructure of muscle foods and roes. Trends Food Sci Technol 12(3-4):122-128.

Guo P, Qi Y, Zhu C, Wang Q (2015) Purification and identification of antioxidant peptides from Chinese cherry (Prunus pseudocerasus Lindl.) seeds. J Funct Foods 19:394-403.

Gupta R, Mathur M, Bajaj VK, Katariya P, Yadav S, Kamal R, Gupta RS (2012) Evaluation of antidiabetic and antioxidant activity of Moringa oleifera in experimental diabetes. J Diabetes $4(2): 164-171$

Helkar PB, Sahoo AK, Patil NJ (2016) Review: Food industry by-products used as a functional food ingredients. Int J Waste Resour 6(3):1-6.

Herregods G, Van Camp J, Morel N, Ghesquière B, Gevaert K, Vercruysse L, Smagghe G 641 (2010) Angiotensin I-converting enzyme inhibitory activity of gelatin hydrolysates and identification 642 of bioactive peptides. J Agric Food Chem 59(2):552-558. 
Hu J, Xu M, Hang B, Wang L, Wang Q, Chen J, Liu X (2011) Isolation and characterization of

an antimicrobial peptide from bovine hemoglobin $\alpha$-subunit. World J Microbiol Biotechnol 27(4):767771.

Hu F, Wu Q, Song S, She R, Zhao Y, Yang Y, Shi R (2016) Antimicrobial activity and safety evaluation of peptides isolated from the hemoglobin of chickens. BMC Microbiol 16(1):287.

Huang D, Ou B, Prior RL (2005) The chemistry behind antioxidant capacity assays. J Agric Food Chem 53(6):1841-1856.

Irshad A, Sharma BD (2015) Abattoir by-product utilization for sustainable meat industry: a review. J Anim Prod Adv 6:681-696.

Jamdar SN, Rajalakshmi V, Sharma A (2012) Antioxidant and ace inhibitory properties of poultry viscera protein hydrolysate and its peptide fractions. J Food Biochem 36(4):494-501.

Jayathilakan K, Sultana K, Radhakrishna K, Bawa AS (2012) Utilization of byproducts and waste materials from meat, poultry and fish processing industries: a review. J Food Sci Technol 49(3):278-293.

Kadam SU, Tiwari BK, Álvarez C, O'Donnell CP (2015) Ultrasound applications for the extraction, identification and delivery of food proteins and bioactive peptides. Trends Food Sci Technol 46(1):60-67.

Kalambura S, Krička T, Kiš D, Guberac S, Kozak D, Stoić A (2016) High-risk bio-waste processing by alkaline hydrolysis and isolation of amino acids. Teh Vjesn 23(6):1771-1776.

Kim SK, Kim YT, Byun HG, Park PJ, Ito H (2001) Purification and characterization of antioxidative peptides from bovine skin. BMB Reports 34(3):219-224.

Kim JB, Bak SG, Jo HG, Cheong SH (2016) Chemical Compositions and Antioxidant Properties of Enzymatic Hydrolysates from Velvet Antler in Elk (Cervus elaphus canadensis). Res J Pharm Biol Chem Sci 7(3):2648-2654.

Korhonen H, Pihlanto-Leppäla A, Rantamäki, P, Tupasela T (1998) Impact of processing on bioactive proteins and peptides. Trends Food Sci Technol 9(8-9):307-319.

Korhonen H, Pihlanto A (2003) Food-derived bioactive peptides-opportunities for designing future foods. Curr Pharm Des 9(16):1297-1308. 
Kumar Y, Yadav DN, Ahmad T, Narsaiah K (2015) Recent trends in the use of natural

antioxidants for meat and meat products. Compr Rev Food Sci Food Saf 14(6):796-812.

Lafarga T, Hayes M (2014) Bioactive peptides from meat muscle and by-products: generation, functionality and application as functional ingredients. Meat Sci 98(2):227-239.

Lafarga T, Hayes M (2017) Effect of pre-treatment on the generation of dipeptidyl peptidaseIV-and prolyl endopeptidase-inhibitory hydrolysates from bovine lung. Irish J Agric Food Res $56(1): 12-24$.

Lee SJ, Kim EK, Hwang JW, Oh HJ, Cheong SH, Moon SH, Park PJ (2010) Purification and characterisation of an antioxidative peptide from enzymatic hydrolysates of duck processing byproducts. Food Chem 123(2):216-220.

Lee SJ, Kim KH, Kim YS, Kim EK, Hwang JW, Lim BO, Park PJ (2012a) Biological activity from the gelatin hydrolysates of duck skin by-products. Process Biochem 47(7):1150-1154.

Lee SJ, Kim YS, Hwang JW, Kim EK, Moon SH, Jeon BT, Park PJ (2012b) Purification and characterization of a novel antioxidative peptide from duck skin by-products that protects liver against oxidative damage. Food Res Int 49(1):285-295.

Lee YS, Phang LY, Ahmad SA, Ooi PT (2016) Microwave-alkali treatment of chicken feathers for protein hydrolysate production. Waste Biomass Valori 7(5):1147-1157.

Lemes A, Sala L, Ores J, Braga A, Egea M, Fernandes K (2016) A review of the latest advances in encrypted bioactive peptides from protein-rich waste. Int J Mol Sci:17(6), 950.

Li B, Chen F, Wang X, Ji B, Wu Y (2007) Isolation and identification of antioxidative peptides from porcine collagen hydrolysate by consecutive chromatography and electrospray ionization-mass spectrometry. Food Chem 102(4):1135-1143.

Li X, Chen B, Xie H, He Y, Zhong D, Chen D (2018) Antioxidant structure-activity relationship analysis of five dihydrochalcones. Molecules 23(5):1162.

Liu DC, Ockerman HW (2001) Meat co-products. In: Hui YH, Nip WK, Rogers RW, Young OA (eds) Meat science and applications. CRC Press, Boca Raton, FL, USA, pp 583-606. 
Liu Q, Kong B, Xiong YL, Xia X (2010a) Antioxidant activity and functional properties of

porcine plasma protein hydrolysate as influenced by the degree of hydrolysis. Food Chem 118(2):403410.

Liu R, Wang M, Duan JA, Guo JM, Tang YP (2010b) Purification and identification of three novel antioxidant peptides from Cornu Bubali (water buffalo horn). Peptides 31(5):786-793.

Liu R, Xing L, Fu Q, Zhou GH, Zhang WG (2016) A review of antioxidant peptides derived from meat muscle and by-products. Antioxidants 5(3):32.

Liu D, Chen X, Huang J, Zhou X, Huang M, Zhou G (2017) Stability of antioxidant peptides from duck meat after post- mortem ageing. Int J Food Sci Technol 52(12):2513-2521.

Lorenzo JM, Munekata PE, Gomez B, Barba FJ, Mora L, Perez-Santaescolastica C, Toldra F (2018) Bioactive peptides as natural antioxidants in food products-A review. Trends Food Sci Technol 79:136-147.

Lynch SA, Mullen AM, O'Neill E, Drummond L, Álvarez C (2018) Opportunities and perspectives for utilisation of co-products in the meat industry. Meat Sci 144:62-73.

Matak KE, Tahergorabi R, Jaczynski J (2015) A review: Protein isolates recovered by isoelectric solubilization/precipitation processing from muscle food by-products as a component of nutraceutical foods. Food Res Int 77:697-703.

Mora L, Reig M, Toldrá F (2014) Bioactive peptides generated from meat industry by-products. Food Res Int 65:344-349.

Mora L, Escudero E, Toldrá F (2016). Characterization of the peptide profile in Spanish Teruel, Italian Parma and Belgian dry-cured hams and its potential bioactivity. Food Res Int 89:638-646.

Mullen AM, Álvarez C, Zeugolis DI, Henchion M, O'Neill E, Drummond L (2017) Alternative uses for co-products: harnessing the potential of valuable compounds from meat processing chains. Meat Sci 32:90-98.

Najafian L, Babji AS (2014) Production of bioactive peptides using enzymatic hydrolysis and 722 identification antioxidative peptides from patin (Pangasius sutchi) sarcoplasmic protein hydolysate. J 723 Funct Foods 9:280-289. 
(2006) Isolation and characterization of four antibacterial peptides from bovine hemoglobin. Peptides 27(9):2082-2089.

Nimalaratne C, Bandara N, Wu J (2015) Purification and characterization of antioxidant peptides from enzymatically hydrolyzed chicken egg white. Food Chem 188:467-472.

Nyberg F, Carlsson A, Hallberg M (2013) Casomorphins/hemorphins. In: Kastin AJ (ed) Handbook of biologically active peptides. Elsevier, San Diego, California, pp 1550-1555.

Onuh JO, Girgih AT, Aluko RE, Aliani M (2014) In vitro antioxidant properties of chicken skin enzymatic protein hydrolysates and membrane fractions. Food Chem 150:366-373.

O'Sullivan SM, Lafarga T, Hayes M, O'Brien NM (2017) Bioactivity of bovine lung hydrolysates prepared using papain, pepsin, and Alcalase. J Food Biochem 41(6):e12406.

O’Sullivan SM, Lafarga T, Hayes M, O'Brien NM (2017b) Antiproliferative activity of bovine blood hydrolysates towards cancer cells in culture. Int J Food Sci Technol 52:1049-1056.

Pateiro M, Borrajo P, Campagnol, PCB, Dominguez R, Tomasevic I, Munekata PES, Barba FJ, Lorenzo JM (2019) Extraction of valuable compounds from meat by-products. In: Barba FJ, RosellóSoto E, Brncic M, Lorenzo JM (eds) Green extraction and valorization of by-products from food processing. CRC Press, Boca Raton, FL, USA, pp 55-89.

Phanturat P, Benjakul S, Visessanguan W, Roytrakul S (2010) Use of pyloric caeca extract from bigeye snapper (Priacanthusmacra canthus) for the production of gelatin hydrolysate with antioxidative activity. LWT-Food Sci Technol 43:86-97.

Phelan M, Aherne-Bruce SA, O’Sullivan D, Fitzgerald RJ, O’Brien NM (2009) Potential bioactive effects of casein hydrolysates on human cultured cells. Int Dairy J 19:279-285.

Power O, Fernández A, Norris R, Riera FA, FitzGerald RJ (2014) Selective enrichment of 747 bioactive properties during ultrafiltration of a tryptic digest of $\beta$-lactoglobulin. J Funct Foods 9:38-47.

Prior RL, Wu X, Schaich K (2005) Standardized methods for the determination of antioxidant capacity and phenolics in foods and dietary supplements. J Agric Food Chem 53(10):4290-4302. 
Raveschot C, Cudennec B, Coutte F, Flahaut C, Fremont M, Drider D, Dhulster P (2018)

Production of bioactive peptides by Lactobacillus species: from gene to application. Front Microbiol 9.

Rogalinski T, Herrmann S, Brunner G (2005) Production of amino acids from bovine serum albumin by continuous sub-critical water hydrolysis. J Supercrit Fluid 36(1):49-58.

Ryan JT, Ross RP, Bolton D, Fitzgerald GF, Stanton C (2011) Bioactive peptides from muscle sources: meat and fish. Nutrients 3(9):765-791.

Ryder K, Bekhit AED, McConnell M, Carne A (2016) Towards generation of bioactive peptides from meat industry waste proteins: Generation of peptides using commercial microbial proteases. Food Chem 208:42-50.

Saiga AI, Iwai K, Hayakawa T, Takahata Y, Kitamura S, Nishimura T, Morimatsu F (2008) Angiotensin I-converting enzyme-inhibitory peptides obtained from chicken collagen hydrolysate. $\mathbf{J}$ Agric Food Chem 56(20):9586-9591.

Salazar-Posada C, López-Padilla A, Cano-Salazar JA (2012) Effect of the pH and of the temperature on the enzymatic hydrolysis of by-products from bovine industries. Rev Lasallista Investig 9(2):26-32.

Sarbon NM Badii F, Howell NK (2013) Preparation and characterisation of chicken skin gelatin as an alternative to mammalian gelatin. Food Hydrocoll 30(1):143-151.

Sarmadi BH, Ismail A (2010). Antioxidative peptides from food proteins: a review. Peptides 31(10):1949-1956.

Selmane D, Christophe V, Gholamreza D (2008) Extraction of proteins from slaughterhouse byproducts: Influence of operating conditions on functional properties. Meat Sci 79(4):640-647.

Sohaib M, Anjum FM, Sahar A, Arshad MS, Rahman UU, Imran A, Hussain S (2017) Antioxidant proteins and peptides to enhance the oxidative stability of meat and meat products: A comprehensive review. Int J Food Prop 20(11):2581-2593.

Tahergorabi R, Beamer SK, Matak KE, Jaczynski J (2011) Effect of isoelectric solubilization/precipitation and titanium dioxide on whitening and texture of proteins recovered from dark chicken-meat processing by-products. LWT-Food Sci Technol 44(4):896-903. 
Tahergorabi R, Hosseini SV (2017) Proteins, peptides, and amino acids. In: Galanakis CM (ed)

Nutraceutical and Functional Food Components. Effects of Innovative Processing Techniques. Elsevier, London, pp 15-38.

Toldrá M, Parés D, Saguer E, Carretero C (2011) Hemoglobin hydrolysates from porcine blood obtained through enzymatic hydrolysis assisted by high hydrostatic pressure processing. Innov Food Sci Emerg Technol 12(4):435-442.

Toldrá F, Aristoy MC, Mora L, Reig M (2012) Innovations in value-addition of edible meat byproducts. Meat Sci 92(3):290-296.

Toldrá F, Mora L, Reig M (2016) New insights into meat by-product utilization. Meat Sci 120:54-59.

Toldrá F, Reig M, Aristoy MC, Mora L (2018) Generation of bioactive peptides during food processing. Food Chem 267:395-404.

Teng D, Fang Y, Song X, Gao Y (2011) Optimization of enzymatic hydrolysis parameters for antioxidant capacity of peptide from goat placenta. Food Bioprod Process 89(3):202-208.

Verma AK, Chatli MK, Kumar PAVAN, Mehta N (2017) Antioxidant and antimicrobial activity of protein hydrolysate extracted from porcine liver. Indian J Anim Sci 87:711-717.

Vidal AR, Cechin CDF, Cansian RL, Mello RDO, Schmidt MM, Demiate IM, ... Dornelles RCP (2018a) Enzymatic hydrolysis (pepsin) assisted by ultrasound in the functional Properties of hydrolyzates from different collagens. Cienc Rural 48(3).

Vidal AR, Ferreira TE, Mello RDO, Schmidt MM, Kubota EH, Demiate IM, Dornelles RCP (2018b) Effects of enzymatic hydrolysis (Flavourzyme ${ }^{\circledR}$ ) assisted by ultrasound in the structural and functional properties of hydrolyzates from different bovine collagens. Food Sci Technol 38:103-108.

Vieira EF, Ferreira IM (2017) Antioxidant and antihypertensive hydrolysates obtained from by801 products of cannery sardine and brewing industries. Int J Food Prop 20(3):662-673. 
Wang JZ, Zhang HAO, Zhang M, Yao WT, Mao XY, Ren FZ (2008) Antioxidant activity of

hydrolysates and peptide fractions of porcine plasma albumin and globulin. J Food Biochem 32(6):693-707.

Wei JT, Chiang BH (2009) Bioactive peptide production by hydrolysis of porcine blood proteins in a continuous enzymatic membrane reactor. J Sci Food Agric 89(3):372-378.

Wen S, Zhou G, Song S, Xu X, Voglmeir J, Liu L, Bai Y (2015) Discrimination of in vitro and in vivo digestion products of meat proteins from pork, beef, chicken, and fish. Proteomics 15(21):3688-3698.

Xu X, Cao R, He L, Yang N (2009) Antioxidant activity of hydrolysates derived from porcine plasma. J Sci Food Agric 89(11):1897-1903.

Yang J, Hu L, Cai T, Chen Q, Ma Q, Yang J, Hong J (2018) Purification and identification of two novel antioxidant peptides from perilla (Perilla frutescens L. Britton) seed protein hydrolysates. PloS One 13(7):e0200021.

Ye N, Hu P, Xu S, Chen M, Wang S, Hong J, Cai T (2018) Preparation and characterization of antioxidant peptides from carrot seed protein. J Food Qual 2018:ID 8579094.

Yu HC, Hsu JL, Chang CI, Tan FJ (2017) Antioxidant properties of porcine liver proteins hydrolyzed using Monascus purpureus. Food Sci Biotechnol 26(5):1217-1225.

Zhu GY, Zhu X, Wan XL, Fan Q, Ma YH, Qian J, Liu XL, Shen YJ, Jiang JH (2010) Hydrolysis technology and kinetics of poultry waste to produce amino acids in subcritical water. $\mathbf{J}$ Anal Appl Pyrol 88:187-191.

Zou Y, Wang W, Li Q, Chen Y, Zheng D, Zou Y, Wu X (2016) Physicochemical, functional 827 properties and antioxidant activities of porcine cerebral hydrolysate peptides produced by ultrasound 828 processing. Process Biochem 51(3):431-443. 
FIGURE CAPTIONS:

2832 Figure 1. Extraction process of bioactive peptides from meat by-products

Figure 1. Antioxidant and antimicrobial determinations generally used to assess the activity of 834 peptides extracted from meat by-products 


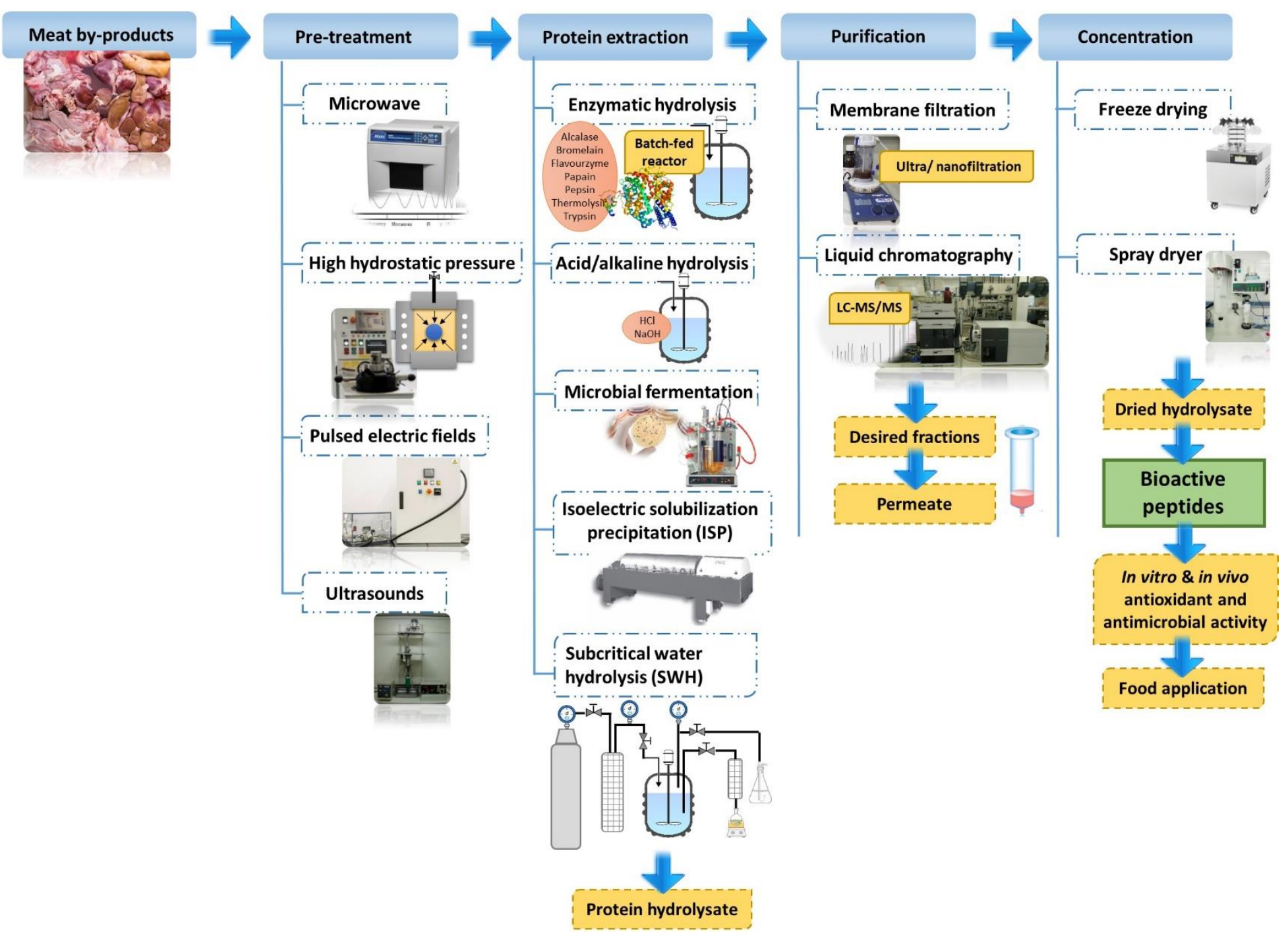

Fig. 1 


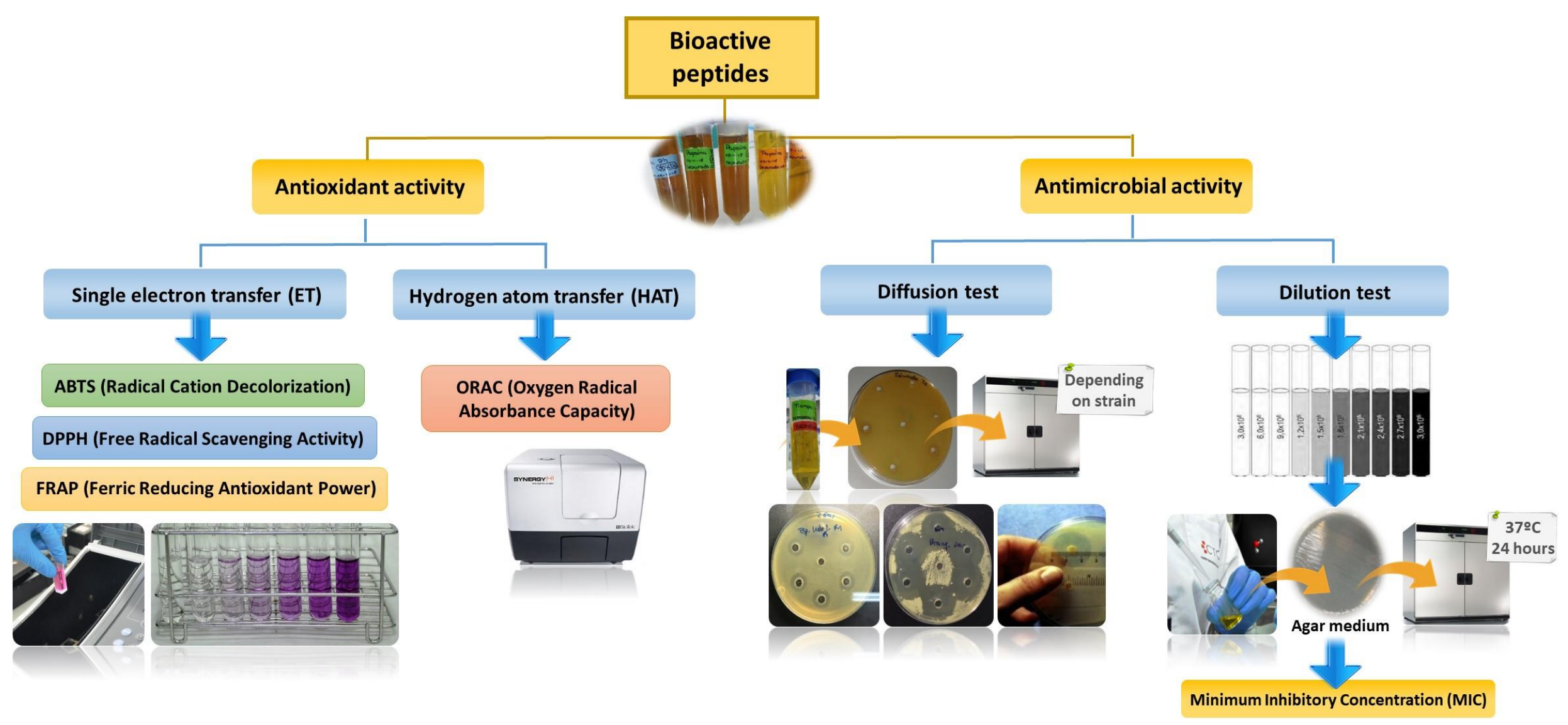

Fig. 2 
Table 1. Antioxidant activity of bioactive peptides isolated from meat by-products after enzymatic hydrolysis.

\begin{tabular}{|c|c|c|c|c|c|c|c|c|c|}
\hline \multirow[b]{2}{*}{ Source } & \multirow[b]{2}{*}{ Enzyme } & \multirow{2}{*}{$\begin{array}{l}\text { Incubation } \\
\text { conditions }\end{array}$} & \multirow[b]{2}{*}{ Deactivation } & \multicolumn{5}{|c|}{ Antioxidant assays } & \multirow[b]{2}{*}{ Reference } \\
\hline & & & & ABTS & $\begin{array}{c}\text { DPPH radical } \\
\text { scavenging activity }\end{array}$ & FRAP & $\begin{array}{c}\mathrm{Fe}^{2+} \text { chelating } \\
\text { ability }\end{array}$ & $\begin{array}{c}\text { ORAC (Trolox } \\
\text { equivalents) }\end{array}$ & \\
\hline \multicolumn{10}{|c|}{ Poultry } \\
\hline \multirow[b]{2}{*}{ Liver } & Pepsin & $37^{\circ} \mathrm{C}, 5 \mathrm{~h}$ & $95^{\circ} \mathrm{C}, 15 \mathrm{~min}$ & $\mathrm{n} / \mathrm{a}$ & $90.7 \%$ & $\mathrm{n} / \mathrm{a}$ & $94.2 \%$ & $\mathrm{n} / \mathrm{a}$ & Chou et al. (2014) \\
\hline & Alcalase & $\begin{array}{c}45^{\circ} \mathrm{C}, 150 \mathrm{~min}, \\
120 \mathrm{rpm}\end{array}$ & $90^{\circ} \mathrm{C}, 10 \mathrm{~min}$ & $19.3 \%$ & $92.8 \%$ & $\mathrm{n} / \mathrm{a}$ & $\mathrm{n} / \mathrm{a}$ & $\mathrm{n} / \mathrm{a}$ & $\begin{array}{c}\text { Chakka et al. } \\
(2015)\end{array}$ \\
\hline \multirow[b]{2}{*}{ Skin } & Alcalase & $\mathrm{pH} 8.0,55^{\circ} \mathrm{C}, 4 \mathrm{~h}$ & \multirow[b]{2}{*}{$95^{\circ} \mathrm{C}, 15 \mathrm{~min}$} & $\mathrm{n} / \mathrm{a}$ & $\cong 35 \%$ & $\mathrm{n} / \mathrm{a}$ & $\cong 95 \%$ & $\cong 3800 \mu \mathrm{M} / \mathrm{g}$ & \multirow[b]{2}{*}{ Onuh et al. (2014 } \\
\hline & $\begin{array}{l}\text { Pancreatin, } \\
\text { pepsin }\end{array}$ & $\mathrm{pH} 2.0,37^{\circ} \mathrm{C}, 2 \mathrm{~h}$ & & $\mathrm{n} / \mathrm{a}$ & $\cong 33 \%$ & $\mathrm{n} / \mathrm{a}$ & $\cong 80 \%$ & $\cong 3200 \mu \mathrm{M} / \mathrm{g}$ & \\
\hline Viscera & Autolytic & $\mathrm{pH} 2.8,55^{\circ} \mathrm{C}, 6 \mathrm{~h}$ & & $721.6 \mu \mathrm{M} / \mathrm{mg}$ & $244.2 \mu \mathrm{M} / \mathrm{mg}$ & $\mathrm{n} / \mathrm{a}$ & $\mathrm{n} / \mathrm{a}$ & $\mathrm{n} / \mathrm{a}$ & $\begin{array}{c}\text { Jamdar et al. } \\
(2012)\end{array}$ \\
\hline \multicolumn{10}{|c|}{ Bovine } \\
\hline $\begin{array}{c}\text { Blood } \\
\text { (fibrinogen) }\end{array}$ & Papain & $\mathrm{pH} 6.5,65^{\circ} \mathrm{C}, 24 \mathrm{~h}$ & $95^{\circ} \mathrm{C}, 10 \mathrm{~min}$ & $\mathrm{n} / \mathrm{a}$ & $\mathrm{n} / \mathrm{a}$ & $25 \mu \mathrm{M} \mathrm{Fe}^{+2} / \mathrm{mg} \mathrm{mL}^{-1}$ & $\mathrm{n} / \mathrm{a}$ & $1000 \mu \mathrm{mol}$ & $\begin{array}{c}\text { O' Sullivan et al. } \\
(2017 \mathrm{~b})\end{array}$ \\
\hline \multirow{3}{*}{ Lung } & Papain & $\mathrm{pH} 6.5,65^{\circ} \mathrm{C}, 24 \mathrm{~h}$ & \multirow{3}{*}{$95^{\circ} \mathrm{C}, 10 \min$} & $\mathrm{n} / \mathrm{a}$ & $\mathrm{n} / \mathrm{a}$ & $8 \mu \mathrm{M} \mathrm{Fe}^{+2} / \mathrm{mg} \mathrm{mL}^{-1}$ & $\mathrm{n} / \mathrm{a}$ & $400 \mu \mathrm{mol}$ & \multirow{3}{*}{$\begin{array}{l}\text { O' Sullivan et al. } \\
\text { (2017a) }\end{array}$} \\
\hline & Pepsin & $\mathrm{pH} 2.0,37^{\circ} \mathrm{C}, 24 \mathrm{~h}$ & & $\mathrm{n} / \mathrm{a}$ & $\mathrm{n} / \mathrm{a}$ & $10 \mu \mathrm{M} \mathrm{Fe}^{+2} / \mathrm{mg} \mathrm{mL}^{-1}$ & $\mathrm{n} / \mathrm{a}$ & $400 \mu \mathrm{mol}$ & \\
\hline & Alcalase & $\mathrm{pH} 9.5,60^{\circ} \mathrm{C}, 24 \mathrm{~h}$ & & $\mathrm{n} / \mathrm{a}$ & $\mathrm{n} / \mathrm{a}$ & $6 \mu \mathrm{M} \mathrm{Fe}^{+2} / \mathrm{mg} \mathrm{mL}^{-1}$ & $\mathrm{n} / \mathrm{a}$ & $450 \mu \mathrm{mol}$ & \\
\hline Liver & Thermolysin & $\begin{array}{c}\mathrm{pH} 9.5,37^{\circ} \mathrm{C}, 2 \mathrm{~h}, \\
150 \mathrm{rpm}\end{array}$ & $99^{\circ} \mathrm{C}, 10 \mathrm{~min}$ & $\mathrm{n} / \mathrm{a}$ & $\begin{array}{c}* 84.1 \%, 82.2 \% \text { and } \\
83.9 \%\end{array}$ & $\begin{array}{c}* 8.8,9.4 \text { and } 8.4, \mu \mathrm{g} \\
\text { Trolox equivalents } / \mathrm{mg}\end{array}$ & $\begin{array}{c}* 55.6 \%, 60.6 \% \\
\text { and } 67.4 \%\end{array}$ & $\mathrm{n} / \mathrm{a}$ & $\begin{array}{l}\text { Di Bernardini et } \\
\text { al. (2011) }\end{array}$ \\
\hline \multirow{5}{*}{ Yak skin } & Alcalase & $\mathrm{pH} 8.0,50^{\circ} \mathrm{C}, 6 \mathrm{~h}$ & \multirow{5}{*}{$\begin{array}{c}100^{\circ} \mathrm{C}, 10 \\
\min \end{array}$} & $\mathrm{n} / \mathrm{a}$ & $6 \mathrm{mg} / \mathrm{mL}\left(\mathrm{IC}_{50}\right)$ & $\mathrm{n} / \mathrm{a}$ & $\mathrm{n} / \mathrm{a}$ & $\mathrm{n} / \mathrm{a}$ & \multirow{5}{*}{ Tian et al. (2017) } \\
\hline & Flavourzyme & $\mathrm{pH} 7.0,50^{\circ} \mathrm{C}, 6 \mathrm{~h}$ & & $\mathrm{n} / \mathrm{a}$ & $4 \mathrm{mg} / \mathrm{mL}\left(\mathrm{IC}_{50}\right)$ & $\mathrm{n} / \mathrm{a}$ & $\mathrm{n} / \mathrm{a}$ & $\mathrm{n} / \mathrm{a}$ & \\
\hline & Pepsin, trypsin & $\begin{array}{l}\mathrm{pH} 2.0,37^{\circ} \mathrm{C}, 6 \mathrm{~h} \\
\mathrm{pH} 7.0,37^{\circ} \mathrm{C}, 6 \mathrm{~h}\end{array}$ & & $\mathrm{n} / \mathrm{a}$ & $2.6 \mathrm{mg} / \mathrm{mL}\left(\mathrm{IC}_{50}\right)$ & $\mathrm{n} / \mathrm{a}$ & $\mathrm{n} / \mathrm{a}$ & $\mathrm{n} / \mathrm{a}$ & \\
\hline & Proteinase K & $\mathrm{pH} 7.5,37^{\circ} \mathrm{C}, 6 \mathrm{~h}$ & & $\mathrm{n} / \mathrm{a}$ & $5 \mathrm{mg} / \mathrm{mL}\left(\mathrm{IC}_{50}\right)$ & $\mathrm{n} / \mathrm{a}$ & $\mathrm{n} / \mathrm{a}$ & $\mathrm{n} / \mathrm{a}$ & \\
\hline & Protamex & $\mathrm{pH} 6.5,50^{\circ} \mathrm{C}, 6 \mathrm{~h}$ & & $\mathrm{n} / \mathrm{a}$ & $4.5 \mathrm{mg} / \mathrm{mL}\left(\mathrm{IC}_{50}\right)$ & $\mathrm{n} / \mathrm{a}$ & $\mathrm{n} / \mathrm{a}$ & $\mathrm{n} / \mathrm{a}$ & \\
\hline
\end{tabular}




\begin{tabular}{|c|c|c|c|c|c|c|c|c|c|}
\hline \multirow{4}{*}{ Hemoglobin } & $\begin{array}{c}\text { Alcalase, } \\
\text { Flavourzyme }\end{array}$ & $\begin{array}{l}\mathrm{pH} 8.5,50^{\circ} \mathrm{C}, 4 \mathrm{~h} ; \\
\mathrm{pH} 7.5,50^{\circ} \mathrm{C}, 6 \mathrm{~h}\end{array}$ & $90^{\circ} \mathrm{C}, 20 \mathrm{~min}$ & $\mathrm{n} / \mathrm{a}$ & $41.9 \%$ & $0.23 \%$ & $63.5 \%$ & $\mathrm{n} / \mathrm{a}$ & $\begin{array}{c}\text { Chang et al. } \\
(2007)\end{array}$ \\
\hline & Alcalase & $\mathrm{pH} 7.5,55^{\circ} \mathrm{C}, 24 \mathrm{~h}$ & \multirow{3}{*}{$100^{\circ} \mathrm{C}, 15 \mathrm{~min}$} & $\mathrm{n} / \mathrm{a}$ & $30.8 \%$ & $\mathrm{n} / \mathrm{a}$ & $\mathrm{n} / \mathrm{a}$ & $\mathrm{n} / \mathrm{a}$ & \multirow{3}{*}{ Wei et al. (2009) } \\
\hline & $\begin{array}{l}\text { Chymotrypsin, } \\
\text { thermolysin } \\
\text { and trypsin }\end{array}$ & $\mathrm{pH} 7.5,35^{\circ} \mathrm{C}, 24 \mathrm{~h}$ & & $\mathrm{n} / \mathrm{a}$ & $24.4 \%$ & $\mathrm{n} / \mathrm{a}$ & $\mathrm{n} / \mathrm{a}$ & $\mathrm{n} / \mathrm{a}$ & \\
\hline & Trypsin & $\mathrm{pH} 7.0,38^{\circ} \mathrm{C}, 24 \mathrm{~h}$ & & $\mathrm{n} / \mathrm{a}$ & $11.5 \%$ & $\mathrm{n} / \mathrm{a}$ & $\mathrm{n} / \mathrm{a}$ & $\mathrm{n} / \mathrm{a}$ & \\
\hline \multirow{7}{*}{ Liver } & Papain & $\mathrm{pH} 6.5,50^{\circ} \mathrm{C}, 6 \mathrm{~h}$ & \multirow{3}{*}{$85^{\circ} \mathrm{C}, 15 \mathrm{~min}$} & $70.6 \%$ & $40.3 \%$ & $\begin{array}{c}12.7 \mathrm{mM} \text { equivalent } \\
\mathrm{FeSO}_{4} .7 \mathrm{H}_{2} \mathrm{O}\end{array}$ & $\mathrm{n} / \mathrm{a}$ & $\mathrm{n} / \mathrm{a}$ & \multirow{3}{*}{$\begin{array}{l}\text { Verma et al. } \\
\quad(2017)\end{array}$} \\
\hline & Alcalase & $\mathrm{pH} 8.0,50^{\circ} \mathrm{C}, 6 \mathrm{~h}$ & & $74.6 \%$ & $42.3 \%$ & $\begin{array}{c}13.7 \mathrm{mM} \text { equivalent } \\
\mathrm{FeSO}_{4} .7 \mathrm{H}_{2} \mathrm{O}\end{array}$ & $\mathrm{n} / \mathrm{a}$ & $\mathrm{n} / \mathrm{a}$ & \\
\hline & Trypsin & $\mathrm{pH} 8.0,37^{\circ} \mathrm{C}, 6 \mathrm{~h}$ & & $86.8 \%$ & $57.5 \%$ & $\begin{array}{c}14.9 \mathrm{mM} \text { equivalent } \\
\mathrm{FeSO}_{4} .7 \mathrm{H}_{2} \mathrm{O}\end{array}$ & $\mathrm{n} / \mathrm{a}$ & $\mathrm{n} / \mathrm{a}$ & \\
\hline & Alcalase & $55^{\circ} \mathrm{C}, 2 \mathrm{~h}$ & $95^{\circ} \mathrm{C}, 10 \mathrm{~min}$ & $79.2 \%$ & $9.9 \%$ & $\mathrm{n} / \mathrm{a}$ & $92 \%$ & $\mathrm{n} / \mathrm{a}$ & $\begin{array}{c}\text { Daamgard et al. } \\
\text { (2014) }\end{array}$ \\
\hline & Papain & $\mathrm{pH} 6.5,37^{\circ} \mathrm{C}, 12 \mathrm{~h}$ & \multirow{3}{*}{$\begin{array}{l}95-100^{\circ} \mathrm{C}, 10 \\
\min \end{array}$} & $\mathrm{n} / \mathrm{a}$ & $37 \%$ & $\mathrm{n} / \mathrm{a}$ & $\mathrm{n} / \mathrm{a}$ & $\mathrm{n} / \mathrm{a}$ & \multirow{3}{*}{ Yu et al. (2017) } \\
\hline & Pepsin & $\mathrm{pH} 3.0,37^{\circ} \mathrm{C}, 12 \mathrm{~h}$ & & $\mathrm{n} / \mathrm{a}$ & $55 \%$ & $\mathrm{n} / \mathrm{a}$ & $\mathrm{n} / \mathrm{a}$ & $\mathrm{n} / \mathrm{a}$ & \\
\hline & Alcalase & $\mathrm{pH} 8.0,50^{\circ} \mathrm{C}, 12 \mathrm{~h}$ & & $\mathrm{n} / \mathrm{a}$ & $42 \%$ & $\mathrm{n} / \mathrm{a}$ & $\mathrm{n} / \mathrm{a}$ & $\mathrm{n} / \mathrm{a}$ & \\
\hline \multirow{5}{*}{ Plasma } & Bromelain & $\mathrm{pH} 6.5,50^{\circ} \mathrm{C}, 24 \mathrm{~h}$ & \multirow{2}{*}{$90^{\circ} \mathrm{C}, 20 \mathrm{~min}$} & $\mathrm{n} / \mathrm{a}$ & $\cong 30 \%$ & $\begin{array}{c}\cong 400 \mathrm{mM} \text { equivalent } \mathrm{FeSO}_{4} / \mathrm{g}\end{array}$ & $\mathrm{n} / \mathrm{a}$ & $\cong 10 \mathrm{mM}$ & \multirow{2}{*}{ Bah et al. (2015) } \\
\hline & $\begin{array}{c}\text { Fungal } \\
\text { proteases }\end{array}$ & $\mathrm{pH} 6.5,50^{\circ} \mathrm{C}, 24 \mathrm{~h}$ & & $\mathrm{n} / \mathrm{a}$ & $\cong 50-60 \%$ & $\begin{array}{l}\cong 750-1000 \mathrm{mM} \\
\text { equivalent } \mathrm{FeSO}_{4} / \mathrm{g}\end{array}$ & $\mathrm{n} / \mathrm{a}$ & $>10 \mathrm{mM}$ & \\
\hline & Alcalase & $\mathrm{pH} 8.0,55^{\circ} \mathrm{C}, 5 \mathrm{~h}$ & $\begin{array}{l}95^{\circ} \mathrm{C}, 5 \mathrm{~min}, \\
\mathrm{pH} 7.0\end{array}$ & $\mathrm{n} / \mathrm{a}$ & $76.5 \%$ & $1407.9 \mu \mathrm{M}$ & $12.0 \%$ & $\mathrm{n} / \mathrm{a}$ & Liu et al. (2010) \\
\hline & Pepsin & $\mathrm{pH} 2.0,37^{\circ} \mathrm{C}, 5 \mathrm{~h}$ & \multirow{2}{*}{$100^{\circ} \mathrm{C}, 3 \mathrm{~min}$} & $\mathrm{n} / \mathrm{a}$ & $48.4 \%$ & $\mathrm{n} / \mathrm{a}$ & $\cong 25 \%$ & $\mathrm{n} / \mathrm{a}$ & \multirow{2}{*}{ Xu et al. (2009) } \\
\hline & Papain & $\mathrm{pH} 8.0,37^{\circ} \mathrm{C}, 16 \mathrm{~h}$ & & $\mathrm{n} / \mathrm{a}$ & $43.1 \%$ & $\mathrm{n} / \mathrm{a}$ & $\cong 8 \%$ & $\mathrm{n} / \mathrm{a}$ & \\
\hline Skin collagen & $\begin{array}{c}\text { Cocktail } \\
\text { proteases }\end{array}$ & $\mathrm{pH} 7.5,37^{\circ} \mathrm{C}, 24 \mathrm{~h}$ & $100^{\circ} \mathrm{C}, 3 \mathrm{~min}$ & $\mathrm{n} / \mathrm{a}$ & $87.2 \%$ & $\mathrm{n} / \mathrm{a}$ & $37.4 \%$ & $\mathrm{n} / \mathrm{a}$ & Li et al. (2007) \\
\hline
\end{tabular}




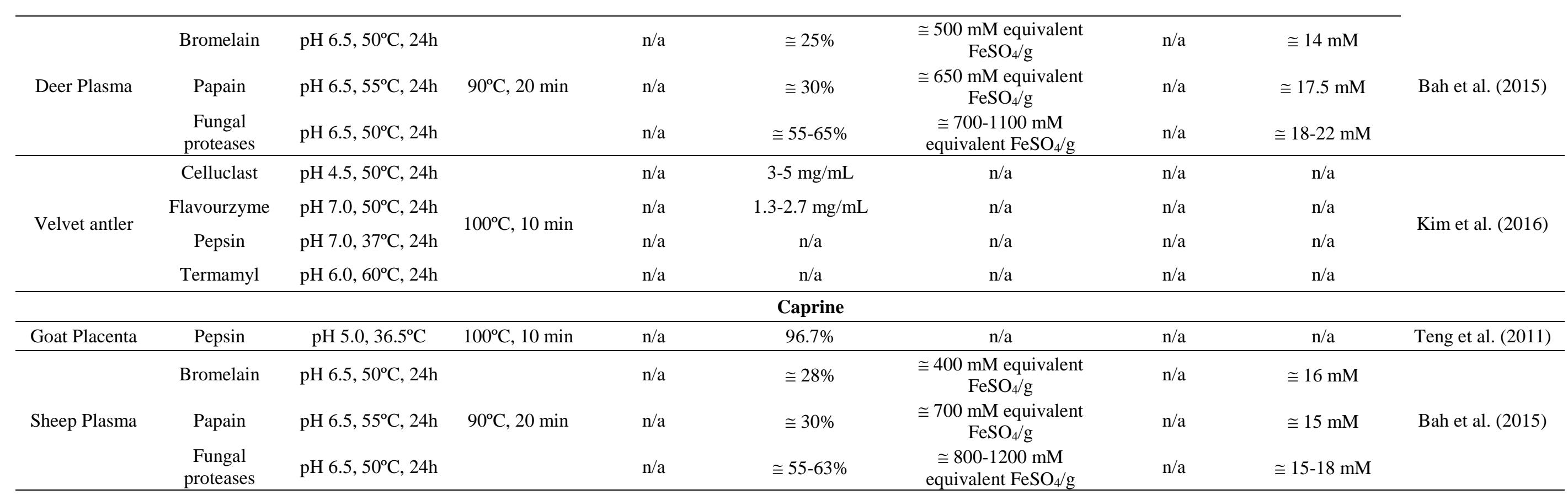

*for non-ultrafiltered, ultrafiltered with $3 \mathrm{kDa}$ and $10 \mathrm{kDa}$; $\mathrm{n} / \mathrm{a}$ : data not available. 
Table 2. Antimicrobial activity of bioactive peptides isolated from meat by-products.

\begin{tabular}{|c|c|c|c|c|c|c|}
\hline \multirow{2}{*}{ Source } & \multirow{2}{*}{ Extraction method } & \multirow{2}{*}{ MW (Da) } & \multicolumn{3}{|c|}{ Antimicrobial assays } & \multirow{2}{*}{ Reference } \\
\hline & & & Strains & $\operatorname{MIC}(\mu \mathrm{M})$ & Inhibition (mm) & \\
\hline \multicolumn{7}{|c|}{ Bovine } \\
\hline \multirow{13}{*}{ Hemoglobin } & \multirow{11}{*}{$\begin{array}{l}\text { Hydrolysis } \\
\text { (Pepsin) }\end{array}$} & 2236.9 & Micrococcus luteus & 671 & $\mathrm{n} / \mathrm{d}$ & Froidevaux et al. (2001) \\
\hline & & \multirow{4}{*}{3150} & Listeria innocua & 38 & 25 & \multirow{4}{*}{ Daoud et al. (2005) } \\
\hline & & & Escherichia coli & 76 & 17 & \\
\hline & & & Micrococcus luteus & 76 & 15 & \\
\hline & & & Salmonella enteritidis & 76 & 16 & \\
\hline & & \multirow{4}{*}{$655-3152$} & Salmonella enteritidis & $5-87$ & \multirow{4}{*}{$\mathrm{n} / \mathrm{d}$} & \multirow{4}{*}{ Nedjar-Arroume et al. (2006) } \\
\hline & & & Escherichia coli & $8-87$ & & \\
\hline & & & Listeria innocua & $1-71$ & & \\
\hline & & & Micrococcus luteus & $9-87$ & & \\
\hline & & & Micrococcus luteus & & & \\
\hline & & $653.7-5437.3$ & $\begin{array}{l}\text { Listeria innocua } \\
\text { Escherichia coli }\end{array}$ & $1-187.1$ & $\mathrm{n} / \mathrm{d}$ & Adje et al. (2011) \\
\hline & \multirow{2}{*}{$\begin{array}{l}\text { Lysis (Ammonium } \\
\text { chloride) }\end{array}$} & \multirow[b]{2}{*}{1992.4} & Candida albicans & & 7.6 & \multirow[b]{2}{*}{ Hu et al. (2011) } \\
\hline & & & Escherichia coli & $\mathrm{n} / \mathrm{d}$ & 10.3 & \\
\hline & & & & Porcine & & \\
\hline \multirow{4}{*}{ Liver } & \multirow{4}{*}{$\begin{array}{l}\text { Hydrolysis } \\
\text { (Trypsin) }\end{array}$} & \multirow{4}{*}{$\mathrm{n} / \mathrm{d}$} & Bacillus cereus & & 16.8 & \multirow{4}{*}{ Verma et al. (2017) } \\
\hline & & & Listeria monocytogenes & $\mathrm{n} / \mathrm{d}$ & 23.4 & \\
\hline & & & Escherichia coli & $\mathrm{n} / \mathrm{d}$ & 18.2 & \\
\hline & & & Staphylococcus aureus & & 18.4 & \\
\hline \multirow{4}{*}{ Plasma } & Hydrolysis & & Escherichia coli & & & \\
\hline & (Bromelain, Papain, & $\mathrm{n} / \mathrm{d}$ & P aeruginosa & $\mathrm{n} / \mathrm{d}$ & $\mathrm{n} / \mathrm{d}$ & Bah et al. (2015) \\
\hline & Fungal proteases) & & Staphylococcus aureus & & & \\
\hline & & \multicolumn{4}{|c|}{ Poultry } & \\
\hline \multirow{4}{*}{ Liver } & \multirow{4}{*}{ Fermentation } & \multirow{4}{*}{$\mathrm{n} / \mathrm{d}$} & Bacillus cereus & & 28 & \multirow{4}{*}{ Chakka et al. (2015) } \\
\hline & & & Listeria monocytogenes & & 30 & \\
\hline & & & Micrococcus luteus & $\mathrm{n} / \mathrm{d}$ & 18 & \\
\hline & & & Yersinia enterocolitica & & 18 & \\
\hline
\end{tabular}




\begin{tabular}{ccc}
\hline $\begin{array}{c}\text { Hydrolysis } \\
\text { (Alcalase) }\end{array}$ & Micrococcus luteus & 12 \\
\hline
\end{tabular}

n/a: data not available; $\mathrm{n} / \mathrm{d}$ : not determinated. 